\title{
THE SCOTTISH SEAWEED RESEARCH ASSOCIATION
}

\author{
By F. N. Woodward, B.Sc., Ph.D., F.R.I.C., F.R.S.E. \\ Institute of Seaweed Research, Musselburgh
}

The production of chemicals from the brown seaweeds is one of the oldest branches of the chemical industry, having its origin as far back as 1720 when soda was first produced from kelp in France, and soon after taken up in Ireland, Scotland and Norway. Until the early nineteenth century this was the only source of this chemical on which the glass and soap industries were built up. When the cheap Leblanc soda later became competitive the industry was able to switch to potash and iodine production, a demand for which had arisen about the same time. This industry reached sizeable proportion, as is evidenced by the fact that in I 820 more than 20,000 tons of kelp were produced in the Outer Hebrides, involving the collecting and burning of about a million tons of cast weed.

History repeated itself again, however, as in the middle of the century cheaper sources of potash and iodine were found, and by about 1870 the industry was struggling for survival. Foreseeing the end, E. C. C. Stanford, the chief chemist of the principal company operating in this field, investigated that part of the seaweed which had been burnt during the previous I 50 years in the hope that it might contain further chemicals of potential value to industry. As a result, he discovered alginic acid in I883, suggested a constitution, and found it to be a colloid not unlike cellulose in composition and properties. Stanford was, however, fifty years in advance of the times and the industry virtually came to an end before the close of the century without any use having been made of his discovery.

As kelp production in the Outer Hebrides and Orkney had been the principal means of livelihood of the inhabitants of these islands, the loss of markets resulted in considerable depopulation, a trend which has continued until recent times.

Many efforts have been made during recent years, however, to prevent this decline and various projects have been suggested to afford the crofters a means of obtaining a livelihood sufficiently attractive not only to stop depopulation but, if possible, to reverse the trend. One obvious possibility was to attempt the establishment of a new industry based on the Islands' seaweed resources, although it was quite obvious that any attempted revival of the old industry to produce the inorganic chemicals soda, potash and iodine would not meet the case. Several things had happened, however, since the demise of the old 
industry which suggested that a new one could be built up on modern lines, provided fundamental data were obtained and new techniques developed.

In I929, C. W. Bonniksen, who was then working in the Chemistry Department of University College, London, reinvestigated the alginic acid discovered by Stanford fifty years earlier, and he conceived the idea that it might be possible to produce cellophane-like material from this algal chemical. In pursuance of this idea, he and a number of his university colleagues formed a company for the purpose of collecting brown seaweed, extracting alginic acid therefrom and converting it into cellophane, Despite almost insuperable difficulties some measure of success had been achieved by 1939, when a small factory was in operation at Bellochantuy on the Mull of Kintyre, although the outbreak of the war put a stop to the commercial fruition of this project. However, the earlier work was not wasted, as after two or three years of war it became obvious to the Government that a substitute for jute hessian required for camouflage purposes was urgently needed; furthermore, it was abundantly clear that the basic starting material would have to be found in Britain.

The Ministries of Supply and Home Security therefore set in train a number of projects and collaborative investigations aimed at developing a camouflage textile from alginic acid which it was hoped could be obtained in adequate quantities from indigenous seaweed. This development involved the design and construction of three factories for the production of alginic acid; the responsibility of establishing these and operating them on behalf of the Government was given to Bonniksen and his colleagues. At the same time, fundamental and technical investigations were carried out in several University and Government laboratories and in the laboratories and workshops of a number of textile firms, aimed at the production first of a yarn from alginic acid and subsequently the fabrication of a textile suitable for camouflage purposes.

Success followed their combined efforts, although by the time that the work was complete the need for this material had decreased, as the Japanese were then being pushed back and their threat to the Indian jute supplies minimized.

As a direct outcome of this wartime work there were three large and wellequipped factories established on the west coast of Scotland, but once the wartime need for alginate fabrics lapsed there was a very grave risk that the new seaweed chemical industry would, after all, fail to become established on a permanent basis. The wartime investigations had revealed many gaps in our knowledge. For instance, little was known about the type, location and availability of the brown seaweeds growing in Scottish inshore waters. Next to nothing was known about the chemical composition of even the common species, and no methods for harvesting the sublittoral brown algae had been developed.

The Scottish Seaweed Research Association was therefore formed towards the end of I944 at the instigation of the Scottish Council on Industry, the Ministry of Supply, the Scottish Office, the Department of Scientific and Industrial 
Research, the Marine Stations, and semi-official and independent organizations interested in seaweed utilization, to provide the basic information on which it was hoped that non-governmental interests could build up an industry based on Scottish seaweed, primarily with a view to bringing useful employment to the crofter population of the Scottish Highlands and Islands.

From the outset it was realized that a combined sociological and applied marine biological experiment of this magnitude required an unconventional approach on the widest possible basis, and the pattern which has been followed is probably unique in the annals of marine science or industrial development.

A programme of research and development was outlined and the problems there defined have subsequently been investigated by the Association's own staff of botanists, chemists, chemical engineers and engineers, and by fifteen University and Government or state-aided laboratories, in close collaboration with the interested industry and the appropriate Government departments and Ministries.

The Seaweed Research Association's early operations were based on accommodation made available by the Chemistry Department of the University of Edinburgh, but the growth of the Association's activities and the University's need for all its laboratory facilities at the termination of hostilities resulted in accommodation having to be found elsewhere. Since 1947 the Association's headquarters have been the Institute of Seaweed Research at Inveresk Gate, an old mansionhouse standing in II acres of land which has been converted to house chemical, botanical and engineering laboratories and workshops and the necessary library and office facilities. In addition, four outstations at Oban and Dunbar on the mainland, Kirkwall in Orkney, and Lochmaddy in North Uist, have been set up from which the survey and experimental vessels have operated.

Although the original research and development programme has not yet been completed, considerable progress has been made both by the Association's staff and by its extra-mural collaborators.

Investigations so far completed have covered the development of methods for the quantitative survey of brown seaweed beds (Walker, 1947a), and their application to the Scottish littoral (Walker, $1947 b$; Gibb, 1950) and sublittoral zones (Walker, I947 $a$, 1950); the study of ecological factors (Walker, I948; Moss, I948, I950 a, $b$; Black, I950 $b$; Black \& Dewar, 1949), and the determination of optimum conditions of weed growth by controlled culture (Smith \& Walker, I948).

With a view to developing new and extended uses of seaweed and seaweed products, studies of the chemistry of algal chemicals have been made (Percival \& Ross, I948b, 1949, I950 $a, b$ 195I; Chanda \& Percival, I950; Connell, Hirst \& Percival, 1950), methods of analysis developed (Cameron, Ross \& Percival, 1948; Percival \& Ross I948a; Black, Cornhill, Dewar, Percival \& Ross, 1950), and determinations of the chemical composition of the 
principal indigenous brown algae and its variation with species, season, age, environment, etc., carried out (Black, I948 $a, b, c$; I949; I950 a, c).

Methods have also been developed for the production of such constituents and their derivatives as are found to be of potential technical value (Bashford, Thomas \& Woodward, I950; Black, Dewar \& Woodward, I95I), and the value of seaweed as a component of animal feed and as a fertilizer assessed.

As the ultimate success of an industry based on seaweed must depend upon adequate supplies at a reasonable cost, the efforts of the engineering staff have been largely directed to the development of economic harvesting techniques (Mackenzie, I947; Jackson, I95I) and the determination of optimum conditions of drying, grinding and handling.

The Association is not a commercial organization, but is so constituted that any individual or organization in Britain in any way interested in the utilization of seaweed can become a member by payment of a nominal fee. By this means scientific and technical data as it becomes available can be and is made use of with the minimum of delay by the universities, research organizations and by industry.

The Board of Management of the Scottish Seaweed Research Association has always realized however, that, in addition to being responsible for providing the basic information on which a rural industry can be established, it has the far more important and exacting task of ensuring that this is understood and applied in such a manner as will benefit the rural community without spoliation of any of the nation's natural marine resources.

This has involved the putting into effect of a sizeable public relations and educational programme by means of wide circulation of technical and progress reports, press releases, and semi-popular articles (cf. Jackson I948), the production and display of informative films and the giving of lectures, radio talks, demonstrations, exhibitions and discussions, and the holding of informal meetings at which the need for balanced conservation techniques has been stressed.

This programme, amongst other things, has been aimed at showing both the crofter and lay public and the interested industry that, largely because of increasing population pressure and consequent depletion of the country's non-renewable mineral reserves, increasing use will inevitably have to be made of our renewable resources (Woodward, I950 $a, b$ ). As Britain's agricultural and forestry techniques are as advanced as any in the world, and as a very high proportion of the land area is already under extensive cultivation, the sea is virtually the only untapped indigenous source of new organic material.

That the operations of the Association and those associated with it have not been without success is indicated by the fact that its original membership has doubled since its formation in 1944; whereas in 1944 there were no companies specifically harvesting seaweed, now there are two about to commence operations. In I944 there were five companies in Britain using seaweed for 
chemical production or agricultural use, now there are eight. There has, in addition, been a significant expansion within the industry during this time, and as a result cast weed is now collected in S. Uist, N. Uist, Benbecula, Barra, Lewis, Tiree, the Orkneys and in the Fraserburgh and Peterhead areas. The total tonnage of seaweed collected in Scotland has increased sevenfold in the last five years, and the total number of collectors has increased sixfold during that time. As a direct outcome of this expansion in the industry there is now no male unemployment in S. Uist.

Alginate production is at the time of writing Britain's major seaweed industry, and this chemical now sells in twenty countries abroad as well as in the home market. British agar production has similarly developed since the end of the war. Whilst accurate figures for the output of the five British alginate and agar-producing firms are not available, it is fairly certain that the industry is producing these chemicals to the value of about $£ 700,000$ per annum at the present time, a not inconsiderable portion of which represents wages paid to the seaweed collectors and the operatives employed in the four Scottish seaweed processing factories located near Girvan, Oban and Lochboisdale. As this industry, which is still expanding, has virtually been built up since the war, it can reasonably be claimed that the $£ \mathrm{I} 20,000$ so far provided by the Treasury from the Development Fund, together with the additional $f$ I I, 500 subscribed by industry and private interests to further the work of the Association, has been a sound investment, for only as the result of this research and development work and that of the Association's member firms has this been made possible.

Much, however, still remains, to be done, as commercial outlets for algal chemicals other than alginic acid and agar have yet to be established, and the mechanical harvesting of Scotland's 10,000,000 tons of brown seaweed and adequate resources of red weed have yet to be carried out on the commercial scale.

A list of publications so far issued or submitted for publication under the auspices of the S.S.R.A. (up to October I950) is herewith appended.

\section{BIBLIOGRAPHY}

BASHFord, L. A., Thomas, R. S. \& Woodward, F. N., I950. Manufacture of algal chemicals. Part I. Production of alginates from brown marine algae. Fourn. Soc. Chem. Ind., Vol. 69, pp. 337-43.

BLACK, W. A. P., I948 a. Seasonal variation in chemical constitution of some common British Laminariales. Nature, Vol. I6r, p. I74.

- I948b. Seasonal variation in chemical constitution of some of the sublittoral seaweeds common to Scotland. Part I. Laminaria cloustoni. Part II. Laminaria digitata. Part III. Laminaria saccharina and Saccorhiza bulbosa. Fourn. Soc. Chem. Ind., Vol. 67, pp. 165-76.

- 1948c. Seasonal variation in chemical composition of some of the littoral seaweeds common to Scotland. Part I. Ascophyllum nodosum. Fourn. Soc. Chem. Ind., Vol. 67, pp. 355-7. 
BLACK, W. A. P., I949. Seasonal variation in chemical composition of some of the littoral seaweeds common to Scotland. Part II. Fucus serratus, Fucus vesiculosus, Fucus spiralis and Pelvetia canaliculata. Fourn. Soc. Chem. Ind., Vol. 68, pp. I83-9.

I $1950 \mathrm{a}$. Seasonal variation and chemical composition of the common British Laminariaceae. Fourn. Mar. Biol. Assoc., Vol. xxIx, pp. 45-72.

I $1950 \mathrm{~b}$. Effect of depth of immersion on the chemical constitution of some of the sublittoral seaweeds common to Scotland. Fourn. Soc. Chem. Ind. Vol. 69, pp. $16 \mathrm{I}-5$.

- I I950 c. The effect of the seasonal variation in the cellulose content of the common Scottish Laminariaceae and Fucaceae. Fourn. Mar. Biol. Assoc., Vol. xxix, No. 2, pp. 379-87.

Black, W. A. P., Cornhill, W. J., Dewar, E. T., Percival, E. G. V. \& Ross, A. G., 1950. An improved method for the extraction of combined fucose in seaweeds. fourn. Soc. Chem. Ind. Vol. 69, pp. 317-20.

Black, W. A. P. \& Dewar, E. T., I949. Correlation of some of the physical and chemical properties of the sea with the chemical constitution of the algae. Fourn. Mar. Biol. Assoc., Vol. xxviII, pp. 673-99.

BLACK, W. A. P., DEWAR, E. T. \& WoodWARD, F. N. I95I. Manufacture of algal chemicals. Part II. Laboratory scale isolation of mannitol from brown marine algae. Fourn. Soc. Chem. Ind. (in the Press).

Cameron, M. C., Ross, A. G. \& Percival, E. G. V., I948. Methods for the routine estimation of mannitol, alginic acid, and combined fucose in seaweeds. Fourn. Soc. Chem. Ind., Vol. 67, pp. I6I-4.

Chanda, S. K. \& Percival, E. G. V., I950. The xylan of Rhodymenia palmata. Nature, Vol. I66, pp. 787-8.

Connell, J. J., Hirst, E. L. \& Percival, E. G. V., I950. The constitution of laminarin. Part I. The laminarin of Laminaria cloustoni. Fourn. Chem. Soc., I950, pp. 3494-500.

GibB, D. C., 1950. A survey of the commoner fucoid algae on Scottish shores. Fourn. Ecology, Vol. 38, pp. 253-69.

JACKson, P., I948. Scottish seaweed resources. Scottish Geographical Mag., Vol. 64, No. 3, pp. 136-44.

- 1950. Utilisation of marine algae. Proc. U.N. Scientific Conference on the Conservation $\mathcal{E}$ Utilisation of Resources, Vol. xII.

- I95I. Sublittoral seaweed harvesting. Part I. Cutting and entrainment method (first stages) and the intermittent grapnel. Fourn. Inst. Civil Engineers (in the Press).

MaCkenZIE, W., I947. Seaweed harvesting methods. Engineer, Vol. I84, pp. 337-9; $373-5 ; 387-9$.

Moss, B. L., I948. Studies in the genus Fucus. Part I. On the structure and chemical composition of Fucus vesiculosus from three Scottish localities. Annals of Botany, Vol. xII, pp. 267-79.

- I950a. Part II. The anatomical structure and chemical composition of receptacles of Fucus vesiculosus from three contrasting habitats. Annals of Botany, Vol. xIv, pp. 395-4IO.

I $1950 b$. Part III. Structure and development of the attaching discs of Fucus vesiculosus. Annals of Botany, Vol. xIV, pp. 4IO-I9.

Percival, E. G. V. \& Ross, A. G., I948 $a$. A colorimetric method for the estimation of alginic acid in seaweed specimens. Fourn. Soc. Chem. Ind., Vol. 67, pp. 420-I.

- I948b. Cellulose of marine algae. Nature, Vol. I62, p. 895.

— 1949. Marine algal cellulose. Fourn. Chem. Soc., I949, pp. 304I-3. 
Percival, E. G. V. \& Ross, A. G., I950a. Fucoidin. Part I. Isolation and purification of fucoidin from brown seaweeds. Fourn. Chem. Soc., I950, pp. 717-20.

- I950 b. Part II. The hydrolysis of a methylated fucoidin prepared from Fucus vesiculosus. Fourn. Chem. Soc., 1950, pp. 827-32.

- I95I. The constitution of laminarin. Part II. The soluble laminarin of Laminaria digitata. Fourn. Chem. Soc. (in the Press).

SMITH, M. MCL. \& WalkeR, F. T., I948. Seaweed culture. Nature, Vol. I62, p. 3 I.

WALKER, F. T., I947a. Sublittoral seaweed survey. Part I. Development of a viewbox spring grab technique for sublittoral weed survey. Part II. Survey of Scapa Flow, Orkney. Part III. Survey of Bay of Firth, Orkney. Fourn. Ecology, Vol. 35, pp. 166-85.

— 1947b. Seaweed survey of Scotland-Fucaceae (April I945-December I946). Proc. Linnean Soc., London Session 159, Pt. 2, pp. 90-99.

_ I948. Sublittoral seaweed surveys; relationship between algal growth and depth. Nature, Vol. I6I, p. 977.

- 1950. Sublittoral seaweed survey of Orkney. Fourn. Ecology, Vol. 38, pp. 139-65.

WOODWARD, F. N., I950 $a$. Creatable resources. The development of new resources by applied technology. Proc. U. N. Scientific Conference on the Conservation and Utilisation of Resources, Vol. I, pp. I3I-5.

- 1950b. Creatable resources. Fourn. Roy. Inst. Chem., Vol. 74, pp. 9-14. 